\title{
Relationship Between Degree of Obesity and Vitamin D Level in Obese Women Applying to A Family Medicine Outpatient Clinic
}

Nazli HACIAGAOGLU1', Huseyin CETIN¹, Halim Omer KASIKCI ${ }^{1}$, Engin Ersin SIMSEK ${ }^{1}$

1 Department of Family Medicine, Dr Lutfi Ki rdar Tra ining and Research Hospital, Istanbul, TURKEY

\begin{abstract}
Aim: The aim of this study was to investigate the relationship between the degree of obesity and vitamin D level in obese women who applied to a family medicine outpatient clinic.

Methods: In our cross-sectional and descriptive study, 297 obese female patients who applied to our family medicine outpatient clinic were included. The patients were evaluated by the researcher in the polyclinic, sociodemographic information and medical history was obtained, anthropometric measurements were made and vitamin D results were recorded.

Results: The mean age of the 297 female patients included in the study was $44.7 \pm 11.7$ years. A significant relationship was found between the degree of obesity and vitamin $D$ level $(p=0.001)$.. Statistically, a significant relationship was detected between the presence of menopause and vitamin $D$ level ( $p=0.000)$.

Conclusions: In the present study, it was observed that as the degree of obesity increased, the level of vitamin $D$ decreased. And, vitamin $D$ levels of the women in menopause were higher than the women who were not in menopause. Vitamin D supplementation during menopause may explain this unexpected relationship. Family physicians should make vitamin D supplementation in addition to diet and other recommendations in obese patients when necessary.

Keywords: Menopause, Obesity, Primary Care, Vitamin D
\end{abstract}

Corresponding Author: Nazli HACIAGAOGLU drnazliunver@gmail.com

Received: July 18, 2021; Accepted: July 31, 2021; Published Online: August 30, 2021

Cite this article as: Haciagaoglu Nazli, Cetin, H., Kasikci, H. O., Simsek, E. E. (2021). Relatıonshıp Between Degree Of Obesıty And Vitamın D Level In Obese Women Applyıng To A Famıly Medıcıne Outpatient Clınıc. European Health Literacy Journal 2(4), 30-37. 


\section{Introduction}

Obesity is one of the most important problems threatening public health. Obesity is more common among women in society and is a health problem with an increasing incidence day by day (1). Obesity is a complex and multifactorial disease. It contributes to the development of various health problems, including type 2 diabetes mellitus, cardiovascular disease, hypertension, hyperlipidemia, cerebrovascular disease, various cancers, obstructive sleep apnea syndrome, liver steatosis, gastroesophageal reflux, polycystic ovary syndrome, osteoarthrosis and depression, and creates a heavy burden on health budgets of societies (2). It is defined by the World Health Organization (WHO) as "excessive fat accumulation in the body that presents a risk to health". In general, the total body fat percentage is between $15-20 \%$ for adult males and $25-30 \%$ for adult females. When this rate exceeds $25 \%$ in males and $30 \%$ in females, or a body mass index (BMI) over $30 \mathrm{~kg} / \mathrm{m} 2$, this is defined as obesity (3). Several factors, such as dietary habits, sedentary lifestyle, genetic factors, prenatal factors, vitamin D deficiency, drug use, maternal age and sleeping pattern are considered to have an effect in the development of obesity (4).Adipose tissue has a critical role in the regulation of fatty acid homeostasis throughout the body. Previous studies support the hypothesis that fatty tissue is an endocrine organ that synthesizes adipokines involved in many metabolic events (5).

Vitamin $D$ is known as a fat-soluble prohormone with a secosteroid structure that is mostly produced in the skin in response to sunlight. Following metabolic changes, it is converted to calcitriol, which takes part in calcium and phosphate metabolism (6). In addition, it regulates glucose transporter 4 (GLUT-4) expression in skeletal muscle and stimulates GLUT-4 translocation in fatty tissue. Vitamin $D$ is an essential vitamin for human health and its deficiency can be associated with serious health problems. Thus, it is of great importance to detect preventable and treatable vitamin D deficiency primarily in risk groups (7). In some studies conducted in Turkey, vitamin D deficiency was found in $51.8 \%$ and vitamin D insufficiency in $20.7 \%$ of individuals (8). Lipogenesis is stimulated in cases with increased calcium transport to adipose tissue, while lipolysis is suppressed. As a result of this, triglyceride accumulation occurs in adipose tissue. Previous studies emphasized that vitamin D can play a role in the development of obesity through these effects (9).

One of the main purposes of primary healthcare services is to detect risk factors at an early stage that could lead to disease development and to fight against changeable risk factors. The purpose of this current study was to investigate the relationship between vitamin $D$ level and degree of obesity in obese women who applied to our family medicine outpatient clinic.

\section{METHOD}

This sectional study included 297 female patients between age 18-70 with $B M I \geq 30$ who applied to the S.B.Ü. Dr. Lütfi Kırdar Kartal City Hospital Family Medicine Outpatient Clinic between 01.01.202001.04.2020 and who accepted to participate by signing a voluntary consent form. Male patients under 18 years old with $\mathrm{BMI}<30$ were excluded from the study. The study data consisted of the patients' demographic, clinical and laboratory findings. The patients were evaluated by the researcher and their height $(\mathrm{cm})$, weight $(\mathrm{kg})$, waist circumference $(\mathrm{cm})$ and hip circumference were measured. BMI was calculated as $\mathrm{kg} / \mathrm{m} 2$.

Patients with a BMI between 30.0 and 34.9 were classified as mildly obese, those between $35.0-39.9$ as moderately obese, those between 40.0 and 49.9 as 
morbidly obese and those with BMI over 50.0 were considered to be super obese (10).

A level of vitamin $\mathrm{D} \leq 20 \mathrm{ng} / \mathrm{mL}$ was considered as vitamin $D$ deficiency, $21-29 \mathrm{ng} / \mathrm{mL}$ as vitamin $D$ insufficiency and $\geq 30 \mathrm{ng} / \mathrm{mL}$ as vitamin D sufficiency (11).

Ethics committee approval dated 25.11.2020, no: $514 / 190 / 27$ was obtained from our hospital's ethics committee.

\section{STATISTICAL ANALYSIS}

Study data was analyzed with the SPSS 21.0 package program. Descriptive criteria (frequency, percentage, mean, median, and standard deviation and minimum- maximum values) were used in the analysis. Kolmogorov Smirnov test was used as the normality test. Data with abnormal distribution were statistically compared with Kruskal Wallis test. Mann Whitney U test was used in sub-group analysis. Spearman correlation test was used in analysis. In results from the analysis, a p value below 0.05 was accepted as significant.

\section{RESULTS}

Mean age of the 297 female participants was calculated as $44.7 \pm 11.7$ years. Sociodemographic characteristics and anthropometric measurements of the patients included in the study are shown in Table 1

Table 1. Sociodemographic characteristics and anthropometric measurements

\begin{tabular}{|c|c|c|}
\hline & n (\%) & Mean \pm SD \\
\hline \multirow[t]{2}{*}{ Age (years) } & $297(100.0)$ & $44.7 \pm 11.7$ \\
\hline & $\mathbf{N}$ & $\%$ \\
\hline \multicolumn{3}{|l|}{ Education } \\
\hline Primary school and lower & 163 & 54.9 \\
\hline Secondary-High school & 92 & 40.0 \\
\hline University & 42 & 14.1 \\
\hline \multicolumn{3}{|l|}{ Employment } \\
\hline Employee or student & 64 & 21.6 \\
\hline Nonworker & 233 & 78.4 \\
\hline \multicolumn{3}{|l|}{ Marital Status } \\
\hline Married & 235 & 79.1 \\
\hline Single & 62 & 20.9 \\
\hline \multicolumn{3}{|l|}{ Smoking } \\
\hline No/Quit & 236 & 79.4 \\
\hline Yes & 61 & 20.5 \\
\hline \multicolumn{3}{|l|}{ Obesity in Childhood } \\
\hline Yes & 99 & 33.3 \\
\hline No & 198 & 66.7 \\
\hline
\end{tabular}




\begin{tabular}{|l|l|l|}
\hline Obesity in the Family & 209 & 70.4 \\
Yes & 88 & 29.6 \\
No & & \\
\hline State of Menopause & 124 & 41.8 \\
Yes & 173 & 58.2 \\
No & 100 & \\
\hline Diabetes Mellitus & 197 & 33.7 \\
Yes & & 66.3 \\
No & 98 & 33.0 \\
\hline Prediabetes & 199 & 67.0 \\
Yes & $\mathbf{n}(\boldsymbol{\%})$ & Mean \pm SD \\
No & $297(100.0)$ & $38.8 \pm 6.5$ \\
\hline & $297(100.0)$ & $116.2 \pm 14.3$ \\
\hline BMI (kg/m $\left.{ }^{2}\right)$ & $297(100.0)$ & $126.4 \pm 12.0$ \\
\hline Waist Circumference $(\mathbf{c m})$ & &
\end{tabular}

BMI: Body mass index.

100 participants $(33.7 \%)$ were in the mildly obese group, 86 patients $(29.0 \%)$ in the moderately obese group, 93 patients $(31.3 \%)$ in the morbidly obese group and $18(6.1 \%)$ were in the super obese group.

Table 2. Classification of the participants according to their vitamin D levels

\begin{tabular}{|l|l|}
\hline & $\begin{array}{l}\text { Median } \\
\text { (Lowest-Highest) }\end{array}$ \\
\hline $\begin{array}{l}\text { Vitamin D Level } \\
(\mathrm{ng} / \mathrm{mL})\end{array}$ & $\begin{array}{l}16.0 \\
(3.7-78.0)\end{array}$ \\
\hline $\begin{array}{l}\text { Vitamin D Deficiency } \\
(\leq 20 \mathrm{ng} / \mathrm{mL})\end{array}$ & $\mathbf{n}(\%)$ \\
\hline $\begin{array}{l}\text { Vitamin D Insufficiency } \\
(21-29 \mathrm{ng} / \mathrm{mL})\end{array}$ & $199(67.0 \%)$ \\
\hline $\begin{array}{l}\text { Sufficient Level of Vitamin D } \\
(\geq 30 \mathrm{ng} / \mathrm{mL})\end{array}$ & $77(25.9 \%)$ \\
\hline
\end{tabular}


Vitamin D levels of the participants according to their obesity groups are given in Table 3.

Table 3. Vitamin D levels of the participants in terms of obesity groups

\begin{tabular}{|l|l|l|l|}
\hline \multirow{2}{*}{ Obesity Classification } & Vitamin D Deficiency & Vitamin D Insufficiency & $\begin{array}{l}\text { Sufficient Level of } \\
\text { Vitamin D }\end{array}$ \\
\cline { 2 - 4 } & $\mathbf{n}(\%)$ & $\mathbf{n}(\%)$ & $\mathbf{n}(\%)$ \\
\hline Mildly Obese & $56(56.0 \%)$ & $34(34.0 \%)$ & $10(10.0 \%)$ \\
\hline Moderately Obese & $58(67.4 \%)$ & $21(24.4 \%)$ & $7(8.1 \%)$ \\
\hline Morbidly Obese & $72(77.4 \%)$ & $17(18.3 \%)$ & $4(4.3 \%)$ \\
\hline Super Obese & $13(72.2 \%)$ & $5(27.5 \%)$ & $0(0.0 \%)$ \\
\hline
\end{tabular}

Statistically, a significant difference was detected No significant difference was detected between between vitamin $D$ level and the obesity group $(p=0.001)$. The relationship between obesity group vitamin $D$ level and presence of diabetes or and vitamin $\mathrm{D}$ level is shown in Table4. In the post hoc analysis of obesity sub-groups, a statistically significant relationship was detected between the mildly obesemoderately obese groups, mildly obese-morbidly obese groups and mildly obese-super obese groups in vitamin $D$ levels $(p=0.014, p=0.000, p=0.011$, respectively). No statistically significant difference was detected between moderately obese -morbidly obese groups, moderately obese -super obese groups and morbidly obese-super obese groups in vitamin $D$ levels $(p=0.423, p=0.296, p=0.504$, respectively). prediabetes $(p=0.456$ and $p=0.189$, respectively). It was found that $124(41.8 \%)$ of the participants were in the menopause period and the vitamin $\mathrm{D}$ median of the participants in the menopause period was 19.0 (3.7-78.0) $\mathrm{ng} / \mathrm{mL}$, whereas the vitamin $D$ median in those who were not in menopause was 14.0 (6.0-44.0) $\mathrm{ng} / \mathrm{mL}$. Statistically, a significant difference was detected between the presence of menopause and vitamin $D$ level $(p=0.000)$. The relationship between vitamin $\mathrm{D}$ levels of the participants and their diseases and state of menopause is shown in Table 5.

Table5. Relationship of the participants' vitamin D levels with diseas es and menopause

\begin{tabular}{|l|l|l|l|}
\hline & $\mathbf{n}(\%)$ & Vitamin D Level Median (Lowest-Highest) & P \\
\hline Yes & $100(33.7 \%)$ & $16.6(5.4-78.0)$ & 0.456 \\
No & $197(66.3 \%)$ & $16.0(3.7-77.0)$ & \\
\hline Prediabetes & & $15.2(6.0-77.0)$ & 0.189 \\
Yes & $98(33.0 \%)$ & $16.3(3.7-78.0)$ & \\
No & $199(67.0 \%)$ & $19.0(3.7-78.0)$ & $\mathbf{0 . 0 0 0 *}$ \\
\hline Menopause & $124(41.8 \%)$ & $14.0(6.0-44.0)$ & \\
Yes & $173(58.2 \%)$ & & \\
\hline
\end{tabular}




\section{DISCUSSION}

In the present study, a significant relationship was observed between vitamin $\mathrm{D}$ level and degree of obesity. It was observed that the level of vitamin D decreased as the degree of obesity increased. Especially with detection of vitamin D deficiency or insufficiency in obese patients, who are in the high-risk group, replacement of vitamin $\mathrm{D}$ is important in followup and treatment of obesity. It is known that serum vitamin $D$ level is lower in obese patients. Vitamin $D$ is a fat-soluble vitamin and disperses to the liver and serum. The volume of all these fractions increases in obesity. Therefore, serum vitamin D level is found to be approximately $20 \%$ lower in obese individuals (12).

In a meta-analysis performed by Pereira-Santos M. et al., in which they included 84 studies, the relationship of obesity and vitamin D was examined. As a result of this meta-analysis, similar to our study, it was found that obesity was associated with vitamin D deficiency regardless of the patient's age. It is recommended that different studies should be conducted to detect the causes of the relationship between BMI and vitamin D deficiency. Vitamin $D$ deficiency in obese individuals should be treated, while considering the effects of confounding factors such as body weight, dietary intake, physical activity, education level and season (13). Khosravi Z.S. et al. included 75 female patients between ages 20-40 in their study in which they researched the effect of vitamin $D$ supplements on weight. The participants were selected from among overweight and obese patients with BMI>25 and vitamin D deficiency, without any known chronic disease, non-smokers and menstruating regularly. The participants were divided into two groups and one of the groups was given vitamin $D$ treatment for 6 weeks. A significant decrease was observed in the BMI and body weight of the intervention group among 53 patients who completed the study at the end of 6 weeks (14).

In a study conducted by Hussain Gilani et al. on the relationship of obesity and diabetes with vitamin $D$ deficiency, vitamin $\mathrm{D}$ deficiency was detected in $60.6 \%$ and vitamin $D$ insufficiency was detected in $15.6 \%$ of 109 patients included in the study, whereas vitamin D level was sufficient in $23.9 \%$ of the patients. $42.2 \%$ of the study group was overweight, $22 \%$ of them were obese and $35.8 \%$ of them were normal weight. They detected a significant difference between diabetic patients and non-diabetic patients and between BMI and vitamin D status (15).In our study, on the other hand, a significant relationship was detected between BMI and vitamin D level, whereas no relationship was observed with presence of diabetes or prediabetes. In the study performed by Kaddam et al., it was found that prevalence of vitamin $D$ deficiency was higher in obese patients compared to overweight and normal weight individuals (16). In the study of Gannage-Yared et al., postmenopausal female patients between ages 50-87 were analyzed and their mean $25(\mathrm{OH})$ D levels were $19.5 \pm 9.8 \mathrm{ng} / \mathrm{ml}$. A negative correlation was shown between BMI and vitamin D level, similar to our study (17).

Alloubani et al. have demonstrated in their study in which they examined the relationship of vitamin $D$ deficiency with diabetes and obesity in 350 female and male patients between ages 18-60, that vitamin D deficiency was more frequent in women and this frequency increased with an increase in BMI (18). Botella-Carretero et al. detected vitamin $\mathrm{D}$ deficiency in $50.7 \%$ of 73 morbidly obese patients with $\mathrm{BMI} \geq 40$ and they observed a significant relationship between vitamin D level and prevalence of metabolic syndrome (19). Although the number of morbidly obese patients was higher in our study, vitamin $D$ deficiency was detected in $77.4 \%$ of these patients. High rate of 
vitamin $\mathrm{D}$ deficiency can be caused by seasonal or regional differences. Wimalawansa et al. examined related studies in their review, which they conducted to determine the relationship between vitamin $\mathrm{D}$ and diabetes, insulin resistance, obesity and metabolic syndrome. In observational studies, they found that sufficient vitamin $D$ level supported recovery from diabetes, metabolic syndrome and obesity (20). Kang et al. examined children between ages 8-14 they followed during the Covid-19 pandemic. They observed a significant increase in the BMI of the participants and a significant decrease in their vitamin $D$ levels within a one year period (21). As seen in our study, the rate of vitamin $D$ deficiency and insufficiency increases as the degree of obesity increases. Exclusion of male patients from our study and the fact that it was conducted in the winter season, when vitamin $D$ levels can be detected to be lower, constitute the weakness of our study. Vitamin $D$ deficiency is a common condition in the postmenopausal period. Untreated vitamin D deficiency leads to osteoporosis, fracture and other cardio-metabolic risks (22-25). Therefore, nutritional recommendations and vitamin $\mathrm{D}$ supplementation are recommended for postmenopausal elderly women to avoid these risks.

In conclusion, it was observed in this study that as the degree of obesity increased, the level of vitamin D decreased. However, vitamin D levels of the women in menopause were higher than the women who were not in menopause. Vitamin D supplementation during menopause may explain this unexpected relationship. Family physicians should make vitamin D supplementation in addition to diet and other recommendations in obese patients when necessary.

\section{Conflict of interest}

The authors declare that they have no conflict of interest.

\section{REFERENCES}

1. Sert H, Çetinkaya S, Aygın D. D Vitaminin Obezite, Diabetes Mellitus, Hipertansiyon ve Kanser İle İlişkisi. Journal of Human Rhythm. 2015; 1(4): 143-149.

2. Evren B, Topaloğlu Ö. Obezitenin Medikal Tedavisi. Fırat Tıp Dergisi, 2018; 72-77.

3. Birinci Basamak Sağlık Kurumları İçin Obezite ve Diyabet Klinik Rehberi. T.C. Sağlık Bakanlığı, Ankara, 2017.

4. Gürbüz P, Yetiş G, Çelikhan G. Obezite ve yağ dokusu. İnönü Üniversitesi Sağlık Hizmetleri Meslek Yüksek Okulu Dergisi. 2016; 4(2): 3243.

5. Galic S, Oakhill JS, Steinberg GR. Adipose tissue as an endocrine organ. Molecular and cellular endocrinology. 2010; 316(2): 129-139.

6. Özçelik D, Koçer $H$, Kasim İ, Şencan İ, Kahveci R, Özkara A. Vitamin D. Derleme, Review. Turkish Medical Journal 2012; 6(2).

7. Nalbant A, Konuk S. Obezite ile D vitamini, Creaktif protein, hemogram parametreleri ve kan grupları arasındaki ilişki. Ortadoğu Tıp Dergisi. 2018; 10(1): 20-25.

8. Uçar F, Taşlıpınar MY, Soydaş AÖ, Özcan N. Ankara Etlik İhtisas Eğitim Araştırma Hastanesi'ne Başvuran Hastalarda $25-\mathrm{OH}$ Vitamin D Düzeyleri. Eur J Basic Med Sci. 2012; 2: 12-5.

9. Çimen M.B.Y., Çimen Ö.B. Obezite ve D vitamini. Mersin Univ Saglık Bilim Derg. 2016; 9(2): 102-112.

10. Türkiye Endokrin ve Metabolizma Derneği Obezite Tanı ve Tedavi Kılavuzu. 2019.

11. Türkiye Endokrin ve Metabolizma Derneği Osteoporoz ve Metabolik Kemik Hastalıkları Tanı ve Tedavi Kılavuzu. 2020.

12. Walsh, JS, Bowles S, Evans AL. Vitamin D in obesity. Current Opinion in Endocrinology \& Diabetes and Obesity. 2017; 24(6): 389-394.

13. Pereira-Santos $M$, Costa PRF, Assis AMO, Santos CAST, Santos DB. Obesity and vitamin $D$ deficiency: a systematic review and meta-analysis. Obesity reviews. 2015; 16(4): 341-349.

14. Khosravi ZS, Kafeshani M, Tavasoli P, Zadeh $\mathrm{AH}$, Entezari $\mathrm{MH}$. Effect of vitamin $\mathrm{D}$ 
supplementation on weight loss, glycemic indices, and lipid profile in obese and overweight women: a clinical trial study. International journal of preventive medicine. 2018; 9.

15. Gilani SYH, Bibi S, Siddiqui A, Shah SRA, Akram F, Rehman MU. Obesity And Diabetes As Determinants Of Vitamin D Deficiency. Journal of Ayub Medical College. 2019; 31(3): 432-435.

16. Kaddam IM, Al-Shaikh AM, Abaalkhail BA, et al. Prevalence of vitamin $D$ deficiency and its associated factors in three regions of Saudi Arabia: A cross-sectional study. Saudi medical journal. 2017; 38(4): 381.

17. Gannage-Yared MH, Maalouf G, Khalife $S$, et al. Prevalence and predictors of vitamin $D$ inadequacy amongst Lebanese osteoporotic women. British Journal of Nutrition, 2008; 101(4): 487-491.

18. Alloubani A, Akhu-Zaheya L, Samara R, Abdulhafiz I, Saleh A, Altowijri A. Relationship between vitamin $D$ deficiency, diabetes, and obesity. Diabetes \& Metabolic Syndrome: Clinical Research \& Reviews. 2019; 13(2): 1457-1461.

19. Botella-Carretero JI, Alvarez-Blasco F, Villafruela JJ, Balsa JA, Vázquez C, EscobarMorreale HF. Vitamin $D$ deficiency is associated with the metabolic syndrome in morbid obesity. Clinical Nutrition. 2007; 26(5): 573-580.
20. Wimalawansa SJ. Associations of vitamin D with insulin resistance, obesity, type 2 diabetes, and metabolic syndrome. The Journal of steroid biochemistry and molecular biology. 2018; 175: 177-189.

21. Kang HM, Jeong DC, Suh BK, Ahn MB.The impact of the coronavirus disease-2019 pandemic on childhood obesity and vitamin $D$ status. Journal of Korean medical science. 2021; 36(3).

22. Dadonienè J, Čypienè $A$, Rinkūnienè $E$, Badarienè J, Laucevičius A. Vitamin D, cardiovascular and bone health in postmenopausal women with metabolic syndrome. Advances in clinical and experimental medicine. 2018; 27(11): 15551560.

23. Inoyatova NM. (2021). Association Of Vitamin D Deficiency With Risk Factors In Postmenopausal Women. The American Journal of Applied sciences, 2021; 3(04): 7077.

24. Catalano A, Morabito N, Di Stefano et al. Vitamin $D$ and bone mineral density changes in postmenopausal women treated with strontium ranelate. Journal of endocrinological investigation, 2015; 38(8): 859-863.

25. Schmitt EB, Nahas-Neto J, Bueloni-Dias F, Poloni PF, Orsatti CL, Nahas EAP. Vitamin D deficiency is associated with metabolic syndrome in postmenopausal women. Maturitas. 2018; 107: 97-102. 